Mateusz Maria Bieczyński

\title{
Koncepcja sprawiedliwości Gustava Radbrucha
}

DOI: $10.35757 /$ CIV.2011.13.07

\section{Wprowadzenie}

Gustav Radbruch w Filozofii prawa (Rechtsphilosophie, 1932) stwierdził, że „prawo jest rzeczywistością, której sensem jest służenie prawnej wartości; prawnej idei. Pojęcie prawa jest więc nakierowane na ideę prawa" . Myśl ta została przez niego powtórzona następnie w wydanym już po II wojnie światowej „Przedszkolu filozofii prawa" (Vorschule der Rechtsphilosophie, 1948). Zgodnie $z$ jego założeniem, wskazaną idea - co w obu dziełach zostało szczególnie mocno podkreślone - „może być jedynie sprawiedliwość” ${ }^{2}$, i to tylko pojmowana obiektywnie, a więc jako określenie relacji między ludźmi. W świetle przytoczonych wypowiedzi sprawiedliwość jako idea jest centralnym pojęciem całej teorii prawa Radbrucha, a wyjaśnienie jej teoretycznej struktury i funkcji - głównym celem. Niniejszy artykuł stanowi próbę ujęcia filozoficznoprawnej koncepcji niemieckiego teoretyka prawa właśnie przez pryzmat tak rozumianej sprawiedliwości.

\footnotetext{
Mateusz Maria Bieczyński - doktor nauk prawnych, historyk sztuki, krytyk wykładowca prawa autorskiego na Uniwersytecie Artystycznym w Poznaniu.

1 G. Radbruch: Rechtsphilosophie, w: R. Dreier, S.L. Paulson: Gustav Radbruch. Rechtsphilosophie, Heidelberg 2003, s. 34 (tłumaczenie autora). Wydanie polskie: Filozofia prawa, przekład E. Nowak, przedmowa R. Dreier, S.L. Paulsen, przedmowa do wyd. pol. J. Zajadło, Wydawnictwo Naukowe PWN, Warszawa 2009.

2 G. Radbruch: Rechtsphilosophie..., s. 34.
} 
Niniejsze opracowanie zostało podzielone na trzy części: 1) pojęcie sprawiedliwości według Radbrucha, 2) sprawiedliwość po II wojnie światowej oraz 3) Radbruchowska sprawiedliwość między prawem natury a pozytywizmem prawnym. Pierwsza $z$ nich została poświęcona podstawowym założeniom metodologicznym, jakie przyjął autor omawianej teorii prawa, konstruując pojęcie sprawiedliwości jako idei prawa, zwłaszcza zaś Arystotelesowskiej teorii sprawiedliwości stanowiącej dla niej punkt wyjścia. Poczynione tu ustalenia będa stanowić wprowadzenie do pogłębionej charakterystyki pojęcia sprawiedliwości w pismach Radbrucha $z$ okresu powojennego. $\mathrm{W}$ obszarze zainteresowania części drugiej znajdzie się historyczne tło przemiany sposobu rozumienia idei prawa przez autora „Przedszkola filozofii prawa”, jak również odpowiedź na pytanie, czy owa przemiana powinna być rozumiana jako wyłom w jego koncepcji, czy też jako jej ewolucja (kontynuacja), polegająca jedynie na przeniesieniu akcentów w dotychczasowych poglądach. Stosownie do przedstawionych wniosków, w części trzeciej zostanie podjęta próba odpowiedzi na pytanie, czy teorię prawa Radbrucha, oparta na pojęciu sprawiedliwości, należy rozumieć jako pozytywistyczna, czy raczej jako naturalistyczna. Całość opracowania zamknie podsumowanie.

\section{Pojęcie sprawiedliwości}

\section{Założenia metodologiczne}

Na teorii prawa Gustava Radbrucha silne piętno odcisnęła filozofia Immanuela Kanta, zwłaszcza zaś dualizm metodologiczny (Methodendualismus) $\mathrm{z}$ jego nadrzędną tezą o niemożliwości wnioskowania „z tego, co jest, o tym. co jest ważne, właściwe, o tym, co być powinno"3. Teza ta w swojej istocie jest odzwierciedleniem za-

3 Ibidem, s. 13. 
sady, że zdaniom imperatywnym nie przysługuje logiczna wartość prawdy i fałszu; że nie są one wypowiedziami prawdziwościowymi. Zgodnie $z$ wypowiedzia samego autora, konieczne jest zrozumienie rozdziału „pomiędzy postrzeganiem wartości a postrzeganiem bytu”, które „funkcjonuja równolegle jako obszary samodzielne, ściśle od siebie oddzielone; jako podstawy metodologicznego dualizmu" ${ }^{4}$, i wyciagnięcie stąd wniosku, że „wypowiedzi powinnościowe można wyprowadzać jedynie $z$ innych wypowiedzi powinnościowych, nie moga zaś być uzasadniane indukcyjnie na podstawie zdań prawdziwościowych"

Jak łatwo zauważyć, przyjęcie metodologicznego dualizmu, jako założenia a priori konstruowanej teorii prawa, musi prowadzić do relatywizmu wartości, na które teoria ta jest nakierowana. Innymi słowy, teza o rozdziale bytu i powinności, leżąca u podstaw koncepcji sprawiedliwości Radbrucha, w nieunikniony sposób prowadzi do relatywizmu, rozumianego jako otwarty katalog wartości, którym prawo powinno służyć. Owa otwartość nie oznacza jednak, że każde rozwiąanie problemu prawnego w formie norm postępowania (prawnych nakazów i zakazów) ma taką samą wartość. Wpisane $\mathrm{w}$ tę koncepcję założenie relatywizmu oznacza natomiast teoretycznoprawną świadomość, że ostateczne i definitywne rozstrzygnięcie co do preferencji aksjologicznych systemu prawnego nie jest możliwe do uzasadnienia w sposób naukowo obiektywny. Autor nie rezygnuje tym samym $z$ określania tych preferencji, zwraca jednak uwage na fakt, że żaden wybór nie będzie wolny od subiektywnych rozstrzygnięćc $\hat{c}^{6}$ Argumentuje, że swoja „metodę określa mianem relatywizmu, ponieważ pozwala ona na przyjęcie słuszności jakiegoś rozstrzygnięcia co do wartości jedynie w związku $\mathrm{z}$ określoną nadrzędna preferencja, tylko w ramach jakiegoś systemu wartości i sposobu widzenia świata wcześniej przyjętego za słuszny, a nie w kategoriach absolutnie obiektywnych" ${ }^{7 "}$.

Ibidem, s. 13.

5 Ibidem, s. 14.

6 Ibidem, s. 18.

7 Ibidem, s. 17. 
Z powyższych ustaleń nie wynika, że pomiędzy wartościowaniem a faktami natury ontologicznej nie zachodzą żadne zależności, ale płynie wniosek nakazujący określać te zależności jako kauzalne, a nie logiczne. W tym znaczeniu relatywizm Radbrucha należy odróżnić od czystego negacjonizmu lub nihilizmu pojęć.

Zgodnie $z$ zaprezentowanym punktem widzenia relatywizm ma dla Radbrucha znaczenie „gwarancji wolnej konkurencji oraz możliwości sporu idei na gruncie prawa". W tym sensie relatywizm $\mathrm{w}$ omawianej teorii jest więc równoznaczny $z$ uznaniem wpisanego w nia pluralizmu demokratycznego. Innymi słowy, relatywizm ustanawia gwarancję wielości punktów widzenia i wartościowań dla wszystkich członków społeczności objętej obowiązywaniem prawa. Można zatem przyjąć, że za pomoca relatywizmu wartości, którym prawo potencjalnie może służyć, Radbruch starał się wyodrębnić ze swojej teorii element subiektywny, w taki sposób, aby możliwe było wskazanie wyłącznie formalnych - a więc obiektywnych - właściwości systemu prawnego jako elementu kultury wyznaczającej ramy dla życia społecznego.

\section{Punkt wyjścia: koncepcja sprawiedliwości Arystotelesa}

W teorii prawa Radbrucha „sprawiedliwość oznacza równość”. Autor odwołuje się tym samym do słynnej koncepcji Arystotelesa. Starożytny filozof wyróżniał sprawiedliwość rozdzielczą (iustitia distributiva) oraz sprawiedliwość wyrównawcza (iustitia commutati$v a)$. Zgodnie $z$ pierwszym rodzajem sprawiedliwości istota postępowania sprawiedliwego polega na tym, że dobro lub konieczne zło jest rozdzielane między ludzi traktowanych w sposób jednakowy w zależności od tego, czy charakteryzuja się pewnymi cechami (jest to kryterium materialne) uznanymi za istotne (np. zasługami, zdolnościami lub potrzebami). Drugi rodzaj sprawiedliwości

Ibidem, s. 516.

9 Ibidem, s. 35. 
oznacza natomiast podział dóbr między wszystkich członków danej społeczności bez przyjmowania dodatkowych kryteriów.

Sprawiedliwość rozdzielcza w wyżej wskazanym znaczeniu stanowi dla Radbrucha wzorcowa forme sprawiedliwości. „W niej - jak pisał - odnajdujemy bowiem ideę sprawiedliwości, na która musi zostać zorientowane pojęcie prawa"10. Ta idea powinna być więc widziana jako zasada prawa; jako jedyna zasada, „dla której miarodajne jest pojmowanie prawa jako rzeczywistości, której sensem jest służenie sprawiedliwości"11.

W taki sposób pojęta idea sprawiedliwości może być uznana za czysto formalna zasadę, utożsamiana $z$ równościa $i$ określająca formę prawa. Polega ona więc na tym, aby „równych traktować $\mathrm{w}$ sposób równy, a różniących się zgodnie $z$ miara ich odmienności, pozostawiając jednak otwarte zarówno pytanie o kwalifikacje jednostek, jak i o sposób ich traktowania" ${ }^{12}$. Dzięki temu formalnemu charakterowi wskazana idea sprawiedliwości nie traci uniwersalnej ważności (bleibt allgemeingültig) ${ }^{13}$.

\section{Sprawiedliwość jako centralne pojęcie idei prawa}

Sprawiedliwość jako zasada prawa powinna być uważana za główna składowa idei prawa, ze względu jednak na jej formalny charakter sama nie wystarczy do tego, aby wyznaczyć jego treść. W tym sensie „idea prawa nie wyczerpuje się w sprawiedliwości” ${ }^{14}$, ponieważ „określa ona jedynie pewien stosunek, nie zaś sposób zachowania (traktowania podmiotów prawa") ${ }^{15}$.

W koncepcji Radbrucha chodzi o sprawiedliwość jako ceche pewnej relacji między ludźmi, a więc o obiektywna sprawiedliwość, a tym samym mniej o sprawiedliwość jako cnotę. Tak pojmowana

${ }^{10}$ Ibidem, s. 36.

${ }^{11}$ Ibidem, s. 37.

${ }^{12}$ Ibidem, s. 54.

${ }^{13}$ Ibidem, s. 74.

${ }^{14}$ Ibidem, s. 54.

${ }^{15}$ Ibidem, s. 54. 
zasada narzuca „tylko” ogólny charakter przepisów (ogólność przepisów). W rzeczywistości społecznej, obiektywnie rzecz ujmując, tak ogólnie pojmowana równość nie jest możliwa. Powinna więc być widziana bardziej jako fikcyjne założenie, tzn. abstrakcyjny termin (signifiant), którego znaczone (signifie) nie daje się wyjaśnić bez przyjęcia dodatkowych założeń (indykatorów). Jak pisze Radbruch: „równość jest zawsze jedynie abstrakcyjna wersją nierówności ujętą $z$ określonego punktu widzenia"16.

Aby dokładniej wyjaśnić pojęcie prawa według Radbrucha, konieczne jest wprowadzenie i wyjaśnienie dwóch innych elementów jego idei: stosowności (die Zweckmäßigkeit) oraz pewności prawa (die Rechtssicherheit). Oba pozostaja ze soba w obustronnym napięciu, podobnie jak $z$ samą sprawiedliwością.

Z wyżej wymienionych kategorii stosowność prawa (celowość), ze względu na obecny $\mathrm{w}$ teorii Radbrucha relatywizm systemu wartości, nie daje się jednoznacznie i obiektywnie zdefiniować. Jest ona najbardziej subiektywnym $z$ elementów całej idei prawa, skonkretyzowanym w każdym pojedynczym wyborze wartości, którym prawo powinno służyć. Dlatego okazuje się, że „pytania o cele prawa oraz cele państwa (polityka) nie daja się od siebie oddzielićc ${ }^{17 ”}$. Nakierowanie na cel powinno zatem określać, „kto jest uznany za równego lub nierównego”, a także „jak powinni być traktowani równi i nierówni”"18.

Relatywizm zawierający się w stosowności prawa „nie może pozostać ostatnim słowem filozofii prawa"19, dlatego niezbędna jest również trzecia część składowa idei. Jest nią zasada pewności prawa, równoznaczna z pozytywizacja prawa ${ }^{20}$. Pewność prawa można ująć jako jasność i określoność przepisów oraz rozstrzygnięć organów państwowych, jak również wyjaśnianie spornych za-

\footnotetext{
${ }_{16}$ Ibidem, s. 74.

${ }_{17}^{17}$ Ibidem, s. 54.

${ }^{18}$ G. Radbruch: Vorschule der Rechtsphilosophie, w: idem: Rechtsphilosophie III, W. Hassemer (red.), C.F. Müller Juristischer Verlag, Heidelberg 1990, s. 144.

${ }^{19}$ G. Radbruch: Rechtsphilosophie..., s. 73.

${ }^{20}$ Ibidem, s. 73 .
} 
gadnień i stosunków prawnych w stosownym czasie. Zasada ta $z$ perspektywy obserwatora (eksternalny punkt widzenia) oznacza również, że to, co jest określone jako prawo, jest powszechnie obowiąujące i powinno być pojmowane jako wiążace. W tym sensie pewność prawa wzmacnia jasne i przejrzyste procedury prawodawstwa oraz orzecznictwa sadowego.

Można powiedzieć, że idea prawa Radbrucha składa się $z$ trzech części: sprawiedliwości, stosowności oraz pewności prawa. $Z$ tych elementów jedynie nakierowanie na cel (stosowność) obarczone jest znamieniem relatywizmu. „Pozostałe dwa stanowia obiektywne wyznaczniki stanowienia i stosowania prawa stojace ponad sporem o wartości ${ }^{21}$ ". Upodabniaja się one bardziej do wewnętrznej moralności prawa w ujęciu Lona Fullera. Radbruch nie uważał jednak, że zgodność ustanowionych przepisów z oboma wyżej wymienionymi elementami stanowi gwarancję ich słuszności.

„Wskazane trzy elementy idei prawa jednocześnie wykluczają się wzajemnie i zarazem sa dla siebie niezbędne"22. Pozostaja więc między sobą $\mathrm{w}$ wielostronnym napięciu. To napięcie prowadzi do pytania o reguly kolizyjne. „Radbruch rozumie obiektywną dana, która określa się mianem prawa, jako wynik daż̇enia do sprawiedliwości”"23, a więc nie jako spełnienie samej sprawiedliwości. Pisze on, że „w rzeczywistości wyłącznie na podstawie wymaganej sprawiedliwości rozstrzygamy, czy określona regulacja ma w ogóle naturę prawna, czy ona w ogóle wypełnia znamiona pojęcia prawa"24.

Sprawiedliwość nie może jednak, zgodnie $z$ filozofią Radbrucha, sama decydować o prawnym charakterze przepisów. Według niego sprawiedliwość jest labilna i zależy od określonych okoliczności oraz od takich zmiennych jak czas czy naród. Sprawiedliwość jako idea prawa „obowiąuje dla konkretnego przedmiotu, jest na ten

${ }^{21}$ Ibidem, s. 74.

22 Ibidem, s. 74.

${ }^{23}$ H. Adachi: Die Radbruchsche Formel, Nomos, Baden-Baden 2006, seria „Studien zur Rechtsphilosophie und Rechtstheorie", t. 44, s. 32.

${ }^{24}$ G. Radbruch: Rechtsphilosophie..., s. 76. 
przedmiot nakierowana oraz jest także przez ten przedmiot, który stara się uregulować, na powrót współdookreślana"25.

Jakkolwiek więc sprawiedliwość wydaje się stanowić zasadę czysto formalna, to zostaje ona jednak zrelatywizowana, dzięki celowości prawa oraz wymogowi jego pewności, do konkretnych realiów funkcjonowania państwa, co w społecznej rzeczywistości stosowania przepisów nie jest możliwe do uniknięcia. „Pewność prawa promuje jego pozytywizację, pozytywne prawo jednak obowiąuje niezależnie od jego sprawiedliwości i celowości" ${ }^{26}$. Zgodnie $z$ koncepcja Radbrucha relacje napięcia pomiędzy wymienionymi elementami idei prawa sa nieusuwalne.

W okresie poprzedzającym II wojnę światową Radbruch nie przyznawał pierwszeństwa żadnemu $z$ wymienionych elementów prawa. Sugerował jedynie, że zasada równości powinna być postrzegana jako pierwszorzędna zasada prawa $\mathrm{w}$ procesie jego stosowania.

\section{Sprawiedliwość po II wojnie światowej}

Radbruchowska argumentacja dotycząca roli sprawiedliwości przed II wojna światową sprawia wrażenie zatrzymanej $\mathrm{w}$ pół drogi. Wydaje się bowiem, że autor nie miał dość odwagi, aby $\mathrm{w}$ pełni sformułować konsekwencje płynace $z$ jego własnej nauki odnośnie do relacji między sprawiedliwością a pewnościa prawa. Radbruch - zgodnie $z$ jego własnymi słowami - „wykazał sprzeczności, nie mogąc ich jednak rozwiąać”, ale jednocześnie uważał, że nie powstaje $\mathrm{w}$ ten sposób wyrwa $\mathrm{w}$ jego koncepcji. Rzeczywistość polityczna jednak, jaka go zastała w późniejszym okresie życia, nadała pytaniu o wskazana relację, tak istotną w świadomości każdego prawnika, szczególny wymiar. Wymusiła bowiem konieczność odpowiedzi na pytanie, czy prawo, mimo „bezprawnej” treści, nadal obowiązuje. Pytanie to domagało się niezwłocznej od-

${ }^{25}$ Ibidem, s. 13.

${ }^{26}$ Ibidem, s. 75 . 
powiedzi; w kontekście okrucieństw nazistowskiego państwa cała teoria Radbrucha wymagała uzupełnienia.

\section{Tlo historyczne}

Czas bezpośrednio po II wojnie światowej to czas systematycznej tranzycji; gruntownych politycznych przemian. Pierwszym krokiem $\mathrm{w}$ rozliczeniu $z$ przeszłością było dla Radbrucha podanie $\mathrm{w}$ wątpliwość zdania wypływającego $z$ nauki pozytywizmu prawnego, że prawo jest prawem. To zdanie - zgodnie $z$ argumentacja Radbrucha - „uczyniło niemieckich prawników bezbronnymi wobec przepisów o zbrodniczej treści”27.

Znaczenie historycznego tła nie może więc pozostać nieuwzględnione przy rekonstrukcji przemiany myślenia niemieckiego teoretyka prawa, jaka dokonała się w nim po wojnie. Doświadczenie czasów nazistowskich odcisnęło silne piętno na jego koncepcji sprawiedliwości, w tym sensie, że wymusiło odpowiedź na najtrudniejsze pytania o granice obowiazywania prawa pozytywnego.

$\mathrm{W}$ tym miejscu można zgodzić się z Alessandro Barrata, który pisze, że „aby pojąć znaczenie pisarstwa Radbrucha, należy nieustannie mieć przed oczami zwiazek pomiędzy historycznymi oraz politycznymi wydarzeniami w Niemczech i na świecie a politycznym oraz pedagogicznym wkładem, którego ślad noszą myśli autora"28.

\section{„Nowe” opracowanie koncepcji sprawiedliwości}

Pytaniem o relację między sprawiedliwością a pewnością prawa Radbruch zajął się ponownie w tekście „Pięć minut filozofii prawa” (Fünf Minuten Rechtsphilosophie, 1945) oraz w dziele „Ustawowe bezprawie i pozaustawowe prawo" (Gesetzliches Unrecht und über-

\footnotetext{
${ }^{27}$ G. Radbruch: Gesetzliches Unrecht und übergesetzliches Recht, w: R. Dreier, S.L. Paulson: Gustav Radbruch. Rechtsphilosophie, C.F. Müller Juristischer Verlag, Heidelberg 2003, s. 215 .

${ }^{28}$ A. Barrata: Relativismus und Naturrecht im Denken Gustav Radbruchs, „Archiv für Rechtsund Sozialphilosophie" 1959, t. XLV, s. 536.
} 
gesetzliches Recht, 1947). To tutaj dokonał uzupełnienia opisanej wyżej relacji pomiędzy elementami idei prawa. Napisał, że „kiedy przepisy świadomie zaprzeczają woli sprawiedliwości, np. kiedy zaprzeczaja prawom człowieka, wówczas brakuje im ważności, naród nie jest im winien posłuszeństwo, a prawnicy muszą w sobie znaleźć dostatecznie dużo odwagi, aby odmówić takim przepisom charakteru prawa"29. Ta myśl, która uprzednio była jedynie sugestia, tutaj została sformułowana jednoznacznie.

Tę zmianę Radbruch nawet jeszcze wzmocnił i ujał precyzyjniej. Sformułował bowiem dwie nawzajem powiazane tezy, które, stosownie do ich treści, nazwał: a) teza o nieznośności (die Unerträglichkeitsthese) oraz b) teza o zaprzeczeniu (die Verleugnungsthese).

Pierwsza $z$ tez, którą można również określić jako „ogólną”, głosi co do zasady, że konflikt pomiędzy sprawiedliwością a pewnościa prawa powinien być rozwiązany na korzyść tej drugiej. Ta reguła miałaby obowiazywać również w tych przypadkach, gdy „prawo pozytywne, wsparte autorytetem państwa [...] jest treściowo niesprawiedliwe i niecelowe"30. To na pierwszy rzut oka kontrowersyjne twierdzenie zostało przez Radbrucha wsparte argumentem, że lepiej jest, gdy system prawa w ogóle funkcjonuje, mimo że zawiera niesprawiedliwe przepisy, niż gdy nie istnieje żaden system prawa.

Od opisanej tezy ogólnej Radbruch przewidywał jednak wyjątek. Zgodnie z nim, „kiedy sprzeczność przepisów prawa pozytywnego ze sprawiedliwościa osiaga taki wymiar, że nie można tego znieść, przepisy te jako "bezprawne" ustępuja sprawiedliwości"31. Innymi słowy, można wskazaną tezę-wyjątek rozumieć w ten sposób, że konflikt pomiędzy sprawiedliwością a prawem pozytywnym wzmocnionym przez zasadę pewności prawa powinien być rozwiązany na korzyść tej pierwszej, jedynie jednak wtedy, gdy narusze-

\footnotetext{
${ }^{29}$ G. Radbruch: Fünf Minuten Rechtsphilosophie, w: R. Dreier, S.L. Paulson: Gustav Radbruch. Rechtsphilosophie..., s. 210.

${ }^{30}$ G. Radbruch: Gesetzliches Unrecht..., s. 217.

${ }^{31}$ Ibidem.
} 
nie sprawiedliwości przez treść przepisów prawa przekroczy pewna (nieokreślona przez autora jednoznacznie) granicę. Wówczas moc obowiązująca prawa stanowionego zostaje przez nie utracona. Powstaje tutaj problem metody wyznaczenia wspomnianej granicy.

Radbruch był świadomy, że „niemożliwe jest znalezienie ostrej linii podziału pomiędzy przypadkami ustawowego bezprawia oraz przepisami, które, mimo niewłaściwej treści, nadal obowiąuja”" ${ }^{2}$, dlatego $\mathrm{w}$ jego teorii powstała luka, która wymaga wypełnienia $\mathrm{w}$ procesie interpretacji pojedynczego przypadku. Tutaj objawia się subiektywny i kazuistyczny aspekt całej teorii. Ostre kontury tezy nie moga przecież być dookreślane jedynie w procesie jej stosowania, mogłoby to bowiem prowadzić do nadużyć. Zagadnienie to będzie przedmiotem namysłu w dalszej części niniejszego opracowania.

W tym miejscu można jednak przyjąc za Hansem Vestem, że omówiona powyżej „Unerträglichkeitsthese, ze względu na swoja prawnotechniczna zawartość, daje się ująć jako zasada prawa $z$ warunkową relacją pierwszeństwa dla pewności prawa"33.

Druga $z$ wymienionych tez - Verleugnungsthese - która jawi się jako wzmocniona wersja pierwszej, głosi, że w przypadkach, „gdy prawo w ogóle nie jest nakierowane na sprawiedliwość; gdy równość stanowiąca rdzeń sprawiedliwości przy stanowieniu prawa jest świadomie negowana, tam tak ustanowione prawo jest nie tylko "niewłaściwym" prawem, ale także w o wiele większym stopniu jest pozbawiane swojej prawnej natury"34.

$Z$ porównania dwóch opisanych tez składających się na tzw. formułę Radbrucha wynika pytanie o różnicę między "niewłaściwym" prawem a nieprawem (Nicht-Recht). Do jej wyjaśnienia konieczne jest uwzględnienie dwóch istotnych aspektów. Po pierwsze, musi zostać wyjaśnione, jak objawia się wykroczenie przeciw sprawiedliwości w przypadku każdej $z$ tez (problem natury ontologicznej),

\footnotetext{
32 Ibidem.

${ }^{33}$ H. Vest: Gerechtigkeit für Humanitätsverbrechen?, Mohr Siebeck Verlag, Tübingen 2006, s. 105 .

${ }^{34}$ G. Radbruch: Gesetzliches Unrecht..., s. 217.
} 
po drugie zaś, jakie konsekwencje powstaja $z$ tego rozróżnienia (problem dotyczacy obowiąywania). Oba te aspekty dają się wyjaśnić jednocześnie. W obu przypadkach chodzi o zagadnienie stosowania opisanych tez.

\section{Praktyczne zastosowanie tzw. formuly Radbrucha w nowej wersji}

Pierwsza przesłanka stosowania tzw. formuły Radbrucha, która musi zostać wymieniona, jest jej ograniczony charakter. Wynika on $z$ ontologicznego charakteru omawianej teorii: formuła odnosi się jedynie do zamkniętego porządku prawnego. Jej zastosowanie ogranicza się wyłącznie do kręgu ludzi, jako jej adresatów, którym w niemieckim porządku prawnym będzie wspólnota określona przez artykuł 20. niemieckiej konstytucji mianem narodu (das Volk).

W piśmiennictwie prawniczym podnoszono, że „nie jest w stu procentach jasne, czy każde zbrodnicze nadużycie w formie przepisów prawnych uchyla dla Radbrucha obowiazywanie określonej normy prawnej, czy też już $z$ samego faktu bycia taka norma nie może ona być więcej nazywana norma prawna" ${ }^{35}$. Dlatego należy zadać pytanie, czy konsekwencje zastosowania tzw. formuly Radbrucha następuja ze skutkiem ex tunc czy ex nunc? Odpowiedź na to pytanie będzie odmienna w przypadku obu wymienionych tez.

Jak zostało już powiedziane, obie tezy moga zostać od siebie odróżnione za pomoca kryterium ostrości. Wykroczenie przeciw sprawiedliwości na podstawie Unerträglichkeitsthese jest - mówiąc słowami Radbrucha - „dalece nieokreślone” (weithin unbestimmt). $Z$ wnioskowania a contrario $z$ Verleugnungsthese dochodzimy do konkluzji, że zastosowanie Unerträglichkeitsthese odnosi się do tych jedynie przypadków, gdy wykroczenie prawa stanowionego przeciwko sprawiedliwości nie jest jawne, a więc gdy cecha sprawiedliwości $\mathrm{w}$ jego treści $\mathrm{w}$ obrębie systemu prawa jest przez prawo-

${ }^{35}$ H. Vest: Gerechtigkeit..., s. 37. 
dawcę przynajmniej postulowana. Taka konstrukcja prowadzi do tego, że na podstawie Unerträglichkeitsthese - w przeciwieństwie do Verleugnungsthese - nie każdy „niewłaściwy” przepis (ungerechte Gesetz) będzie nieważny. Innymi słowy, $\mathrm{z}$ punktu widzenia obowiązywania, pomiędzy przepisami, które na podstawie Unerträglichkeitsthese wykraczaja przeciw sprawiedliwości, a przepisami, które czynia to samo na podstawie Verleugnungsthese, nie zachodzi żadna różnica, ponieważ zarówno „niewłaściwe” prawo (Un-Recht), podobnie jak nieprawo (Nicht-Recht) pozbawione jest mocy obowiąującej. Kiedy jednak w pierwszym przypadku poprzednio obowiązujące prawo traci ważność, to $\mathrm{w}$ przypadku drugim „nieprawo (Nicht-Recht) nie obowiązuje już z samej swojej natury”36. „Niewłaściwe” prawo oraz nieprawo różnią się od siebie mniej niż od obowiąującego prawa. Jak zauważa Vest, „granica pomiędzy obowiąujacym prawem oraz ustawowym bezprawiem jest dla Radbrucha jedynie granica wielkości (nur eine Maßgrenze), ostra granica powstaje natomiast pomiędzy prawem a nieprawem (Nicht-Recht)"37.

Odpowiedź na wskazane pytanie zależy więc od tezy. Pytanie będzie zatem wymagało odpowiedzi osobno dla każdej $z$ tez. Jak pisze Vest, w przypadku Unerträglichkeitsthese „chodzi o [...] prawo, które w wyniku niemożliwego do zniesienia naruszenia zasady sprawiedliwości utraciło moc obowiązujacą ${ }^{38 "}$. W przypadku Verleugnungsthese natomiast przepisy prawa stanowionego nigdy nie nabyły mocy obowiązującej. $Z$ powyższej różnicy wynika więc, że Unerträglichkeitsthese odnosi się do pojęcia obowiazywania prawa, Verleugnungsthese natomiast do pojęcia prawa jako takiego. „Prawo wykraczajace przeciwko sprawiedliwości w stopniu niemożliwym do zniesienia cierpi na brak ważności, podczas gdy przepisy, które nigdy nie były nakierowane na sprawiedliwość, w szczególności zaś na równość, lub im świadomie zaprzeczały, już z samej de-

${ }^{36}$ Ibidem, s. 112.

${ }^{37}$ Ibidem, s. 40, por. G. Radbruch: Vorschule..., s. 151.

${ }^{38}$ H. Vest: Gerechtigkeit..., s. 21. 
finicji nie sa prawem, tylko nieprawem ${ }^{39}$ ". Każdej $z$ tez tzw. formuły Radbrucha przypada więc odrębna funkcja, jakkolwiek jednocześnie obie sa ze soba treściowo ściśle powiązane. Zgodnie z Verleugnungsthese prawo da się zdefiniować, a na podstawie Unerträglichkeitsthese może być podane w watpliwość jedynie jego obowiazywanie. Skutkiem zastosowania obu jest jednak utrata mocy obowiazujacej (ważności) przez prawo pozytywne. Verleugnungsthese działa zatem ze skutkiem ex nunc, Unerträglichkeitsthese natomiast ex tunc.

W dalszej kolejności należy postawić pytanie, kiedy dokładnie teza o nieznośności (die Unerträglichkeitsthese) znajduje zastosowanie. Czy istnieje kryterium rozstrzygajace, do jakiego momentu przepisy prawa stanowionego moga i powinny być potraktowane jako możliwe do zniesienia? Na to pytanie trafnie, choć bardzo ogólnie, odpowiedział Vest: „jedynie wówczas, gdy rozstrzygnięcie na podstawie danej normy prawnej o maksymalnej możliwej niesprawiedliwości jest co najmniej w przybliżeniu trafne i uniwersalne, dany przepis jest prawdziwie niemożliwy do zniesienia"40. Jego twierdzenie jest $z$ cała pewnościa poprawne, niemniej $z$ praktycznego punktu widzenia pozostaje mało użyteczne. Autor uwypukla wprawdzie charakter tej tezy jako wyjątku i próbuje dokonać jej obiektywizacji, pozostaje jednak jedynie na ogólnym poziomie opisu. Nie zbliża się ani o krok do wyjaśnienia pojęcia „nieznośny/ niemożliwy do zniesienia”. Pojęcie to nie jest bowiem „właściwym terminem prawnym. Jako racjonalna kategoria odwołuje się on do ogólnych pojęć, takich jak niewspółmierne ciężary, nadzwyczajne (ekstremalne) okoliczności czy niecodzienne układy zdarzeń" ${ }^{41}$. W swojej nieostrości upodabnia się ono do tzw. klauzul generalnych, których interpretacja ma silnie relatywny charakter, gdyż ich znaczenie pozostaje otwarte.

Jak zostało wykazane, nie każde „nieznośne” prawo stanowione (unerträgliches Gesetz), zgodnie $z$ tezą o nieznośności (Unerträg-

${ }^{39}$ Ibidem, s. 103.

40 Ibidem, s. 106.

${ }^{41}$ Por. F. Saliger: Radbruchsche Formel und Rechtsstaat, C.F. Müller Juristischer Verlag, Heidelberg 1995, s. 42. 
lichkeitsthese), będzie tracić moc obowiąująca. O tym, czy będzie tak w konkretnym przypadku, zdecyduja sytuacje prawne (tj. całokształt norm prawnych znajdujacych zastosowanie w danej sytuacji), przede wszystkim zaś to, w jakim stopniu sprawiedliwość w znaczeniu „równości” została zanegowana. Według tego punktu widzenia prawo stanowione, możliwe do sumarycznego ujęcia $\mathrm{w}$ formie paremii dura lex sed lex, obowiazuje zgodnie $z$ teza o nieznośności (Unerträglichkeitsthese) dopóty, dopóki na jej podstawie w określonej sytuacji każdy adresat norm będzie traktowany w ten sam sposób.

$\mathrm{Na}$ marginesie należy zapytać, czy rozważana teza odnosi się jedynie do pojedynczych przepisów, czy też znajduje zastosowanie w innych, możliwych do pomyślenia sytuacjach prawnych, np. gdy podmiot prawa podlega takim prawnym koincydencjom, że dopiero ich suma tworzy dla niego sytuacje prawna niemożliwa do zniesienia, jakkolwiek każda $z$ norm, którym podlega, widziana osobno nie osiaga takiego stopnia niesprawiedliwości. Na to pytanie jednak u Radbrucha również nie można znaleźć bezpośredniej odpowiedzi.

Brak dookreślenia granicy nieznośności prawa (stopnia jego niesprawiedliwości), która musi zostać przekroczona, aby formuła Radbrucha mogła znaleźć zastosowanie, przesuwa w istocie pytanie o jej znaczenie na sędziowską interpretację przepisów prawnych, dokonywana $\mathrm{w}$ procesie ich wykładni (przede wszystkim $\mathrm{w}$ orzecznictwie sądowym). Na podstawie ogólnych reguł „sędziowska interpretacja jest nakierowana na obiektywny sens norm prawa pozytywnego, tzn. na znaczenie zawarte w tekście prawnym, nie zaś na sens subiektywny, tzn. na autonomiczne przemyślenia osób uczestniczacych $\mathrm{w}$ procesie stosowania prawa"42. Jedynie bowiem na podstawie prawomocnego wyroku określone antyprawo (gegen-Recht) może stać się nieprawem (nicht-Recht) bez konieczności kwestionowania całego systemu prawnego. W tym miejscu powstaje jednak niebezpieczeństwo, że w interesie orzecznictwa (judyka-

${ }^{42}$ G. Radbruch: Vorschule..., s. 129. 
tury) nie leży urzeczywistnianie obiektywnej sprawiedliwości, gdyby miało się to skierować przeciwko zasadzie pewności prawa.

Podsumowując, można zatem mówić o „ograniczonej stosowalności formuły", która odnosi się jedynie do pojedynczych przypadków orzecznictwa w sensie przyjętym przez Franka Saligera. Innymi słowy, pozostaje pytaniem każdego pojedynczego przypadku czy formuła znajdzie zastosowanie. Jakie ma jednak znaczenie powyższy wniosek $z$ teoretycznoprawnego punktu widzenia?

Jak była o tym mowa, „funkcja formuły jako reguły kolizyjnej polega na rozluźnieniu inherentnej państwu prawnemu antynomii, jaka powstaje między sprawiedliwościa a zasada pewności prawa, na najbardziej czułych (dotkliwych) pozycjach naszego poczucia prawa"43. Za Saligerem, $z$ Radbruchowskiej formuły można zatem wyprowadzić trzy istotne i zasadnicze wnioski: 1) konflikt pomiędzy sprawiedliwościa a pewnościa prawa wyklucza możliwość przyjęcia jednego, absolutnego rozwiązania na korzyść jednego $z$ elementów, dlatego w grę wchodzi jedynie relacja pierwszeństwa warunkowego; 2) warunkowa relacja pierwszeństwa wypada na korzyść zasady pewności prawa; 3) pierwszeństwo pewności prawa jest naznaczone przez relatywizujacy warunek niemożliwego do zniesienia naruszenia sprawiedliwości.

Opisane w niniejszym akapicie nowe ujęcie relacji sprawiedliwość-pewność prawa było szeroko dyskutowane w piśmiennictwie filozoficznoprawnym. Stawiano pytanie, czy zawarte w nim uściślenie poglądów należy uznać za wyłom czy jedynie za przeniesienie akcentu w myśli Radbrucha. W tym miejscu wypada udzielić na nie odpowiedzi.

\section{Nowe ujęcie relacji pewności prawa do sprawiedliwości}

Można się zgodzić $z$ poglądem, że „dla tezy o nieznośności znamienne jest, że "nieznośne" - w znaczeniu ekstremalnie niesprawiedliwego - prawo cierpi na brak prawnej mocy obowiazu-

${ }^{43}$ F. Saliger: Radbruchsche..., s. 3. 
jacej”44. Sam Radbruch pisał: „gdzie sprawiedliwość prawa stanowionego osiaga taki zakres, że forsowana przez nie pewność prawa w ogóle nie stanowi przeciwwagi dla niesprawiedliwości, tam zasadzie sprawiedliwości ustępuje niesprawiedliwe prawo"45. Wynika stąd, że sprawiedliwość oraz pewność prawa są wartościami porównywalnymi. Prowadzi to do ponownego postawienia pytania o to, jakie ontologiczne związki łączą oba wskazane pojęcia.

Odpowiedź na to pytanie możemy odnaleźć w następującym cytacie: „gdzie powstaje sprzeczność między pewnościa prawa a sprawiedliwością; pomiędzy treściowo dającym się uchylić, ale pozytywnym (stanowionym) prawem a prawem sprawiedliwym, ale nieujętym $\mathrm{w}$ formie przepisów prawa stanowionego, tam w rzeczywistości występuje konflikt sprawiedliwości z samą sobą; konflikt pomiędzy pozorną a prawdziwa sprawiedliwością"46. Powyższe zdanie - wbrew jego dosłownemu znaczeniu - nie może być rozumiane jako podstawa do utożsamienia obu pojęć, gdyż $\mathrm{w}$ ten sposób ujawnia się między tymi pojęciami pokrewieństwo, które wynika wprost $z$ przyjętych przez Radbrucha wstępnych założeń. Pewność prawa, która może zostać wyrażona w sentencji: „wszystko, co jest dane jako prawo, jest prawem, a wszystko, co jest prawem, powinno być przestrzegane", stanowi podstawowa regułę każdego porządku prawnego, która sama w sobie jest reguła sprawiedliwości formalnej i jako taka powinna być rozumiana.

Ta formuła może jednak pozostawać w konflikcie ze sprawiedliwością w znaczeniu równości. Dlatego Radbruch przyznał pierwszeństwo pewności prawa i ja widział jako „znacząca wartość, również gdy została ona osiagnięta przez niesprawiedliwe przepisy ${ }^{47 "}$. $Z$ tego punktu widzenia mógł mniemać, że „ważniejsze jest samo zakończenie sporu o prawo niż zakończenie go w sposób jedynie słuszny i sprawiedliwy; że istnienie porządku prawnego jest waż-

${ }^{44}$ H. Vest: Gerechtigkeit..., s. 38.

${ }^{45}$ G. Radbruch: Vorschule..., s. 150.

${ }^{46}$ G. Radbruch: Gesetzliches Unrecht..., s. 217.

${ }^{47}$ H. Vest: Gerechtigkeit..., s. 38. 
niejsze niż jego sprawiedliwość czy słuszność"48. Wynika $z$ tego, że pewność prawa może być osiagnięta również przez niesprawiedliwe przepisy.

Pierwszeństwo pewności prawa jest tym samym konsekwencja ontologiczna - conditio sine qua non - każdego systemu prawnego: bez porzadku prawnego opartego na autorytecie przepisów prawo nie może istnieć. Wskazana uwaga stanowi jednak jedynie bazę dla teorii Radbrucha - jest dla niej punktem wyjścia. Jeżeli bowiem prowadzimy dyskusję na temat jakości prawa, to wówczas sprawiedliwość stanowi jej miarę. Każdy system prawny jest lepszy niż stan naturalny w znaczeniu, jaki nadał mu Jeremy Bentham (wojna wszystkich przeciwko wszystkim). Posłuszeństwo pewności prawa określić należy zatem jako wybór mniejszego zła.

Należy stwierdzić, że sprawiedliwość nie zawsze pozostaje w relacji opozycji do zasady pewności prawa. Dlatego pytanie o pierwszeństwo między oboma właściwościami prawa odnosi się jedynie do tych przypadków, gdy nie jest jasne, czy sprawiedliwość rzeczywiście jest osiagnięta i czy dane przepisy prawa stanowionego osiagaja jej jakikolwiek poziom.

\section{Wylom czy kontynuacja?}

Rozwiązanie konfliktu pomiędzy sprawiedliwością a pewnością prawa - według miary, jaka jest warunkowa relacja pierwszeństwa, na korzyść pewności prawa - nie narusza przedstawionych wyżej poglądów niemieckiego teoretyka. Wydaje się, że Radbruch starał się uściślić swoją teorię przez bardziej precyzyjne wyjaśnienie relacji między sprawiedliwościa a pewnościa prawa. Również wskazanie praw człowieka, jako nieprzekraczalnej granicy dla treści prawa pozytywnego (stanowionego), nie zmieniło radykalnie jego koncepcji, ze względu bowiem na jej ogólny charakter również $\mathrm{w}$ tym miejscu nie jest do końca jasne, jakiego rodzaju wykroczenie przeciw prawom jednostki prowadzi do negacji prawa. Zgodnie

${ }^{48}$ G. Radbruch: Rechtsphilosophie..., s. 71. 
z tym ujęciem zasada sprawiedliwości może jedynie częściowo zostać wypełniona treścią. Pojęcie praw człowieka - jako przykładowych wartości, którym prawo powinno służyć - nie jawi się jednak jako wystarczająco znaczace przekształcenie całej koncepcji, aby można było mówić o jej radykalnej zmianie.

W związku $z$ tym trzeba się zgodzić $z$ twierdzeniem Saligera, że Radbruch istotnie zauważył i trafnie nazwał niezaprzeczalne napięcia powstające $\mathrm{w}$ obrębie prawa stanowionego, które należy postrzegać jako podstawową myśl jego nauki o antynomiach prawa. „Najważniejszą antynomia - jak pisze Saliger - jest sprzeczność pomiędzy sprawiedliwościa a pewnościa prawa: tak dalece jak pewność prawa uzasadnia obowiąywanie niesprawiedliwego prawa i tym samym wyklucza niepewność, występuje ona jako konieczne przeciwieństwo sprawiedliwości" ${ }^{49}$. To napięcie w teorii Radbrucha pozostaje niezmienione również po II wojnie światowej. Do tej koncepcji zostały dodane jedynie wyjątki i warunki, dzięki czemu zmierza ona w kierunku większej precyzji, co stanowi nieodzowną konsekwencję doświadczeń czasów nazizmu.

W różnych momentach lektury Vorschule der Rechtsphilosophie można znaleźć dążenie do jasności sformułowań. Radbruch przesunał akcenty. Przed II wojna światowa pisał, że „prawo powinno służyć sprawiedliwości", natomiast po wojnie starał się doprecyzować tę myśl, pisząc, że „prawo jest tym, co ma na celu wprowadzić sprawiedliwość (jako swoją ideę) w rzeczywistość. Pojęcie prawa jest zorientowane na ideę prawa, która wynika $z$ niego jako logiczna konsekwencja"50. W tym zdaniu następuje konkretyzacja tego, co wcześniej wyrażał czasownik „służyć”, który był przez Radbrucha postrzegany jako słowo zbyt słabe i nieostre dla precyzyjnego oddania myśli.

Kiedy mówimy o przemianie koncepcji sprawiedliwości $\mathrm{w}$ teorii Radbrucha, wówczas stawiamy $\mathrm{w}$ istocie pytanie, czy $\mathrm{w}$ jego pismach mamy do czynienia $z$ przełomem, czy raczej $z$ kontynu-

${ }^{49}$ F. Saliger: Radbruchsche..., s. 8.

${ }^{50}$ G. Radbruch: Vorschule..., s. 151. 
acją? Odpowiadając na to pytanie, Erik Wolf argumentuje pragmatycznie, wskazując, że Radbruch nigdy nie zaprzeczył swoim wcześniejszym rozważaniom ${ }^{51}$. Chcąc scharakteryzować ową kontynuację i jej kierunek, można stwierdzić, że koncepcja Radbrucha najpierw miała charakter czysto formalny, później zaś była uzupełniona przez niego od strony treściowej (materialnej), jednak nie tak dalece, aby wiązać się $\mathrm{z}$ całkowita przemianą myśli. Dlatego - jak się wydaje - nie można mówić o wyłomie. Oznacza to zatem, że przed II wojna światowa Radbruch wahał się przed przyznaniem pierwszeństwa jednej $z$ opisywanych części idei prawa. Dążył do ich możliwego zrównoważenia. Starał się akcentować pewność prawa jako gwarancji jego jakości przy równoczesnym dowartościowaniu sprawiedliwości jako jego jądra. W wyniku doświadczeń $z$ czasów nazizmu rozwinął on relację pomiędzy oboma antynomicznymi elementami idei prawa.

Na tym przykładzie widać wyraźnie tę zmianę - co będzie jeszcze przedmiotem namysłu - ale omawiana teoria od początku nie może być postrzegana ani jako konsekwentnie pozytywistyczna, ani jako naturalnoprawna. Trzon jego przemyśleń nie zmienił się również po II wojnie światowej.

\section{Formula Radbrucha między pozytywizmem a naturalizmem prawnym}

Radbruch pisał: „z pojęcia prawa wynika, jakie ono musi być, tzn. 1) rzeczywiste, np. winno przybierać postać empirycznie pojmowanych przepisów, a więc być prawem pozytywnym; 2) jako ucieleśnienie idei prawa musi wypowiadać się o rzeczywistości pozaprawnej wartościująco i motywująco, powinno zatem być normatywne; 3) jako intencjonalne urzeczywistnienie sprawiedliwości, które ma na celu uregulowanie ludzkiego życia, musi być natu-

${ }^{51}$ E. Wolf: Umbruch oder Entwicklung in Gustav Radbruchs Rechtsphilosophie?, „Archiv fur Rechts- und Sozialphilosophie" 1959, t. XLV, s. 483. 
ry społecznej; 4) będąc ucieleśnieniem przysługującej wszystkim sprawiedliwości rozumianej jako równość, musi być generalne" 52 .

Na podstawie tej charakterystyki, która wymienia na pierwszym miejscu pozytywizm i normatywizm prawa, może zostać wyprowadzone twierdzenie, że cała filozofia prawa Radbrucha powinna być uważana za pozytywistyczną. Autor wskazał mianowicie całkiem wyraźnie, że pozytywizacja prawa stanowi najważniejsza podstawę pewności prawa oraz całego systemu prawnego. Stanowi ona konieczny proces, bez którego prawo nie może uzyskać ważności - zyskać mocy obowiązującej. Nieznaczna liczba wyjątków od bezwzględnej zasady obowiazywania każdej normy ustanowionej jako prawo pozytywne, których aktualizacja wymaga silnego uzasadnienia i spełnienia licznych warunków (m.in. wykazania rażącej niesprawiedliwości), prowadzi do uznania teorii Radbrucha za prawnopozytywistyczna.

Jednocześnie jednak nie powinien ujść uwadze fakt, że $z$ silnie konserwatywnego, pozytywistycznoprawnego punktu widzenia przyzwolenie na jakiekolwiek wyjatki od ogólnie obowiąującej mocy prawa stanowionego, wyrażonej $\mathrm{w}$ sentencji: prawo jest prawem (lex est lex), prowadzi do przełamania jego prawnopozytywistycznego charakteru i uczynienia $z$ niej rodzaju teorii pozornej. Jeżeli zatem u Radbrucha materialna (treściowa) ważność prawa jest silnie naznaczona przez tezę o nieznośności (Unerträglichkeitsthese), tzn. zależy od tego, czy prawo urzeczywistnia określona jakość, zgodnie $z$ miara sprawiedliwości, to ta sprawiedliwość musi być widziana przynajmniej jako prawnonaturalny dodatek do prawa pozytywnego. Wynika stąd określenie Radbruchowskiej nauki o idei prawa jako teorii sprawiedliwości prawa pozytywnego (Vest).

Jasne się wydaje, że „w swojej istocie teoria Radbrucha zawiera zaprzeczenie prawnopozytywnej tezy o rozdzielności, zgodnie $z$ która pojęcie prawa pozostaje $\mathrm{w}$ treściowej niezależności od nakazów moralności” ${ }^{33}$. Radbruch pisze również, że „tak samo jak do pojęcia

${ }^{52}$ G. Radbruch: Rechtsphilosophie..., s. 111.

${ }^{53}$ H. Vest: Gerechtigkeit..., s. 22. 
właściwego prawa przynależy jego pozytywny charakter, tak zadaniem prawa pozytywnego jest być właściwym treściowo" ${ }^{4}$.

W piśmiennictwie prawniczym jako określenie filozoficznoprawnego znaczenia tzw. formuły Radbrucha używane jest pojęcie prawa ponadpozytywnego. Sugeruje to, jakoby koncepcja filozofa zbliżała się do prawnonaturalnych koncepcji prawnych. Słuszność użycia takiego oznaczenia bywa jednak kwestionowana. I tak, według Vesta, „taki usus językowy należy odrzucić jako niesłuszny, gdyż "ponadpozytywny" sugeruje brak podstawy obowiązywania prawa"55. Uważa on, że formalna natura prawnej teorii Radbrucha, w której jedynie w pojedynczych przypadkach może być mowa o zakwestionowaniu ogólnej zasady obowiązywania prawa stanowionego, oznacza, że nie można nadać jej prawnonaturalnego charakteru.

Jako rozwiąanie powstającego dylematu odnośnie do kwalifikacji stanowiska niemieckiego filozofa został zaproponowany również termin: prawo naturalne o zmiennej treści ${ }^{56}$. Zwolennicy tego podejścia argumentuja, że ze względu na tzw. słabą tezę o rozdzielności prawa i moralności, która jest wpisana w cała koncepcje Radbrucha, „przynajmniej w przypadkach brzegowych jest zaprogramowany zwiąek prawa i moralności" ${ }^{57}$ i poprzez to przydany jej prawnonaturalny wkład, który przełamuje prawnonaturalny charakter.

Pojęcie prawa naturalnego o zmiennej treści stało się przedmiotem silnej krytyki. Saliger precyzował, że „implikuje ono podstawową (bazowa) wariantywność zawartości (treści) prawa, co nie odpowiada ponadustawowemu prawu Radbrucha”. Jego zdaniem, „zgodnie $z$ neokantowskim podejściem Radbrucha $[\ldots]$, jedynie to

\footnotetext{
${ }^{54}$ G. Radbruch: Rechtsphilosophie..., s. 74.

${ }_{55}$ H. Vest: Gerechtigkeit..., s. 105.

${ }^{56}$ F. Saliger: Radbruchsche..., s. 27: „Ausdrücklich tituliert er (Radbruch) das übergesetzliche Recht, unter Berufung auf Stammler als "Naturrecht mit wechselndem Inhalt", also als ein Recht, das im Unterschied zum klassischen Naturrecht zwar nach Zeit und Ort wandelbar ist, zugleich aber den Anspruch nicht aufgibt, unter den jeweiligen empirischen Verhältnissen objektiv richtiges Recht zu enthalten."

${ }^{57}$ H. Vest: Gerechtigkeit..., s. 116.
} 
ma ogólnie obowiązująca wartość, co ma charakter formalny; co prowadzi do konieczności wzmocnienia przez niego znaczenia prawa pozytywnego przez rozluźnienie dualizmu metodycznego (bytu i powinności) lub jednoznaczne forsowanie sprawiedliwości"58.

Połaczenie elementów obu nurtów filozofii prawa w teorii Radbrucha prowadzi do tego, że „Radbruchowska formuła staje się alternatywa zarówno dla koncepcji pozytywistycznych, jak i naturalnoprawnych"59. Dlatego wyżej rozważane nazewnictwo stanowi jedynie próbę ujęcia omawianej tu teorii $\mathrm{w}$ ramy tradycyjnych, filozoficznoprawnych kierunków.

Przede wszystkim jednak $z$ teorii Radbrucha wynika, że prawo natury oraz pozytywizm prawny moga istnieć równolegle ${ }^{60}$. „Stąd Radbruch nie widzi prawa natury i pozytywizmu prawnego jako dwóch odseparowanych biegunów, ale jako dwa, wprawdzie odmienne, ale obustronnie na siebie oddziaływajace punkty widzenia w obrębie jednej rzeczywistości prawnej ${ }^{61 "}$.

\section{Podsumowanie}

Wydaje się, że Radbruch próbował odnaleźć kompromis pomiędzy prawem natury a pozytywizmem prawnym. Dlatego, zdaniem Saligera, można powiedzieć, że „Radbruch nie odrzuca tezy o czysto wtórnej moralnej naturze sprawiedliwości. Formuła Radbru-

\footnotetext{
${ }^{58}$ F. Saliger: Radbruchsche..., s. 27-28.

${ }^{59}$ H. Vest: Gerechtigkeit..., s. 22.

${ }^{60}$ F. Saliger: Radbruchsche..., s. 12: „Radbruchs These von der Unergründbarkeit einer absoluten Vorrangrelation zwischen Gerechtigkeit und Rechtssicherheit ist weder klassisch naturrechtlich noch rechtspositivistisch. Geltungstheoretisch betrachtet ist die These nicht naturrechtlich, weil sie unabhängig von dem konkret vorrangigen Wert die Vorstellung eines zwar unvernünftigen, aber dennoch verbindlichen positiven Rechts einschließt. Diese dem Positivismus geläufigen Vorstellung wiederstreitet der klassischen Naturrechtsdoktrin. Danach bricht Naturrecht, einmal erkannt, entgegenstehendes positives Recht, so dass positives Recht, das ungerecht und verbindlich zugleich ist, nicht möglich ist. Umgekehrt gilt positives Recht nach der Formel selbst bei Annahme einer bedingten Vorrangrelation zugunsten der Rechtssicherheit nicht gänzlich ohne inhaltliche Rücksichten - eine Konsequenz, die mit rechtspositivistischem Denken unvereinbar ist."

${ }^{61}$ Ibidem, s. 11
} 
cha musi być postrzegana nie tylko jako teoria relacji pewności prawa i jego sprawiedliwości; teoria relacji pozytywizmu prawnego z klasycznym prawem natury, ale również - trzecia płaszczyzna znaczenia - jako teoria stosunku prawa do moralności" ${ }^{62}$.

$Z$ elementu dyskursywnego, który można znaleźć w teorii Radbrucha wynika, że w pytaniu o przynależność jego teorii powinien zostać przesunięty akcent, tak aby móc zmienić jej kwalifikację. Wypada zatem stwierdzić, że jego teoria nie może być uważana wyłącznie za prawnonaturalna lub pozytywistycznoprawna, ale także musi zostać przypisana tzw. trzeciej drodze, otwierajacej w historii filozofii prawa nowe drzwi.

Uznanie przez teoretyka w okresie powojennym naruszenia praw człowieka jako nowej granicy sprawiedliwości prawa uczyniło cała jego koncepcję jeszcze bardziej otwarta. Element dyskursywny, wynikający zarówno $z$ wpisanego $\mathrm{w}$ główne założenia relatywizmu wartości, jak i z zależności sprawiedliwości oraz celowości, został jeszcze po II wojnie światowej wzmocniony w wyniku materialnego dookreślenia prawa pozytywnego przez uznanie praw człowieka za kryterium wyznaczajace granice godziwego prawa. Prawa człowieka ze swej natury buduja konkretne, choć niejednoznaczne kontury dla wykładni obowiazującego prawa.

Taki punkt widzenia na omawiana teorię, który od nazwiska autora określany jest mianem formuly Radbrucha, stanowi wyłom w myśleniu pozytywistycznoprawnym niemieckiej myśli prawniczej. Wszystkie wyżej wymienione problemy ujawniające się przy analizie tej formuły aktualizuja się również przy wykładni tzw. prawa oporu $z$ artykułu 20 III 4 niemieckiej konstytucji, który zawiera gwarancje podstawowych zasad prawa wraz z przyzwoleniem nieposłuszeństwa wobec każdego, kto podejmuje działania zmierzające do zniweczenia tego porządku prawnego, jeżeli żadna inna droga nie będzie możliwa.

Wykładnia prawa oporu $\mathrm{w}$ powiazaniu $\mathrm{z}$ filozoficznoprawna koncepcją Radbrucha unaocznia, że stanowiąca jej jądro formuła

62 Ibidem, s. 27. 
nie jest sprzeczna $z$ porządkiem prawnym i jego podstawowymi zasadami, lecz musi być postrzegana jako jego część, naznaczona historycznym piętnem. Jedynie jako immanentna systemowo mogła stać się częścią porządku prawnego większości państw europejskich. Jak to precyzyjnie wyraził Vest: „dokładnie ten obiektywny sens polegający na możliwości zaprzeczeniu ważności prawa pozytywnego jest $\mathrm{w}$ tezie Radbrucha konstytutywny, przy czym teza o zaprzeczeniu (Verleugnungsthese) nie okazuje się niezgodna $z$ systemem prawnym. W obiektywnym sposobie jej odczytania może ona wnieść bardzo istotny wkład w określenie tego, co jako prawo może w ogóle być rozpoznane ${ }^{63}$.

$Z$ tego punktu widzenia formuła Radbrucha przywodzi na myś1 tzw. normę podstawowa Hansa Kelsena i problem jej pozytywizacji wewnattrz systemu prawnego. $\mathrm{W}$ obu przypadkach chodzi mianowicie o źródło mocy obowiąującej prawa stanowionego i uzasadnienie jego autorytetu. Formuła Radbrucha, podobnie jak norma podstawowa, stanowi więc jądro pojęcia prawa, dzięki któremu jest możliwe rozstrzygnięcie na podstawie norm ustanowionych jako obowiazujące. W obu przypadkach jądro to okazuje się usytuowane na zewnatrz systemu norm prawnych, postrzeganego $z$ perspektywy autopoietycznej (którego system ten jako taki sam nie generuje). Różnica między nimi jest zakres ich możliwego zastosowania. Kiedy bowiem normę podstawowa Kelsena możemy przywoływać jako podstawę obowiązywania każdego możliwego do pomyślenia porzadku norm prawnych, to formułe Radbrucha jedynie w przypadkach porządków, które nie wykraczaja przeciw sprawiedliwości ponad możliwą do zniesienia miarę. W ten sposób sprawiedliwość pozostaje centralnym pojęciem Radbruchowskiej koncepcji prawa, przesadzając o jej niepozytywistycznym charakterze.

${ }^{63}$ H. Vest: Gerechtigkeit..., s. 111. 